ORIGINAL ARTICLE / ARTIGO ORIGINAL

Factors associated with lack of mammography: National Health Survey, 2013

\title{
Fatores associados à não realização de mamografia: Pesquisa Nacional de Saúde, 2013
}

\author{
Yonna Costa Barbosa' (D), Ana Gabriela Caldas Oliveira" (D), Poliana Pereira Costa Rabêlo'II (D), \\ Francelena de Sousa Silva"l' (D), Alcione Miranda dos Santos ${ }^{\text {III (D) }}$
}

ABSTRACT: Introduction: Mammography is the main screening test for early detection of breast cancer; however, its access is not equal for all women in Brazil. The objective of this study was to analyze the factors associated with not having this examination done in a period of less than two years in Brazil and according to macro-region, considering sociodemographic characteristics, health conditions, lifestyle, and the use of health services. Method: Cross-sectional study using data from the National Health Survey in Brazil (Pesquisa Nacional de Saúde - PNS). The sample consisted of 10,571 women ( $\geq 40$ years old) living in all Brazilian regions. Poisson regression model with hierarchical approach was used to estimate prevalence ratios. Results: The characteristics associated with not getting a mammogram were: age $\geq 60$ years, low schooling, living without a partner, negative health self-rating, having some chronic disease, no regular exercise, not getting a clinical breast examination for up to one year or a Pap smear for up to three years, not seeing a doctor in the last year, not having health insurance, feeling discriminated by a health professional, and being enrolled in a family care unit. Sociodemographic factors were prominent in the North and Northeast, while in other regions, health conditions and health behavior were predominant. Conclusion: Variables related to the use of health services were especially important in not getting a mammogram. Measures should be taken in each macro-region of Brazil to reduce disparities in access to mammography.

Keywords: Early detection of cancer. Breast neoplasms. Mammography. Women’s health. Health status disparities.

'Hospital Universitário, Universidade Federal do Maranhão - São Luís (MA), Brazil.

"Hospital São Domingos, Hospital do Câncer Aldenora Bello, Universidade Federal do Maranhão - São Luís (MA), Brazil.

"'Universidade Federal do Maranhão - São Luís (MA), Brazil.

Corresponding author: Yonna Costa Barbosa. Rua Barão de Itapari, 227, CEP 65020-070, São Luís, MA, Brazil.

E-mail: barbosa.yc@gmail.com

Conflict of interest: none to declare - Funding sources: none. 
RESUMO: Introdução: O acesso à mamografia, principal exame de detecção precoce do câncer de mama, não é igualitário entre as mulheres brasileiras. Objetivou-se analisar os fatores associados à não realização desse exame num período inferior a dois anos no Brasil e por macrorregião, considerando-se características sociodemográficas, condições de saúde, hábitos de vida e uso dos serviços de saúde. Método: Estudo transversal que utilizou dados da Pesquisa Nacional de Saúde (PNS). A amostra consiste de 10.571 mulheres ( $\geq 40$ anos) residentes em todas as regiões brasileiras. Modelo de regressão de Poisson com abordagem hierarquizada foi utilizado para estimar razões de prevalência. Resultados: As características associadas à não realização de mamografia foram: idade $\geq 60$ anos, baixa escolaridade, viver sem companheiro, avaliar negativamente o próprio estado de saúde, possuir alguma doença crônica, não praticar exercício físico, não realizar o exame clínico da mama até um ano, ou o exame de Papanicolaou até três anos, não ter consultado com médico no último ano, não possuir plano de saúde, sentir-se discriminada por profissional de saúde e ter cadastro em uma unidade de saúde da família. Variáveis sociodemográficas se sobressaíram no Norte e Nordeste; e nas outras regiões, condições de saúde e hábitos de vida. Conclusão: Variáveis relacionadas ao uso dos serviços de saúde tiveram destaque na não realização da mamografia. Ações que reduzam a desigualdade no acesso ao exame devem ser adotadas em cada macrorregião do Brasil.

Palavras-chave: Deteç̧ão precoce de câncer. Neoplasias da mama. Mamografia. Saúde da mulher. Desigualdades em saúde.

\section{INTRODUCTION}

Breast cancer is the leading cancer diagnosis in women in Brazil and worldwide ${ }^{1,2}$. Notably, in developed countries, the number of deaths has been decreasing, but in developing countries, the opposite is true, which may possibly be related to less access to early detection and timely treatment ${ }^{3}$.

In Brazil, $80 \%$ of breast cancer diagnoses occur in advanced stages, and this scenario is worse for women with low education who depend on the Unified Health System (SUS) ${ }^{4,5}$. Thus, access to mammography, the main early detection examination, is not equal among Brazilian women. Population-based studies indicate that higher education and income, living in urban areas and in the most developed regions of the country are factors related to a greater number of women getting a mammographic examination ${ }^{6-11}$.

Health condition also seems to be determinant for mammography, since women with a positive assessment of their health are more likely to submit to the examination ${ }^{6,7,9}$. Research conducted in a state capital in Northeast Brazil found a negative relationship between smoking and participation in mammogram screening ${ }^{12}$.

The use of health services is another factor that may influence the participation of the female public in breast cancer control actions. Women who visited a doctor in the last year are more likely to have a mammogram ${ }^{6.8}$, just as those with health insurance ${ }^{11}$.

In Brazil, the investigation of factors associated with women's participation in early detection of breast cancer has focused mainly on sociodemographic characteristics. Thus, the scope of this study included aspects still little explored at the national level, such as health 
conditions, lifestyle and characteristics related to the use of health services. The study was carried out at the national level and by macro-region, thus allowing the observation of the peculiarities referring to each one. Accordingly, the main objective of this study was to identify the factors associated with not performing a mammogram in a period of less than two years among Brazilian women nationwide and by macro-region, covering sociodemographic characteristics, health conditions, lifestyle and use of health services.

\section{METHODS}

We conducted a population-based cross-sectional study based on data from the National Health Survey (Pesquisa Nacional de Saúde - PNS), conducted from August 2013 to February 2014, with the objective of evaluating the health, lifestyle and health care of the adult population in Brazil.

The PNS is the largest survey conducted in Brazil regarding the health situation of the population. It is part of the Integrated System of Household Surveys (SIPD) of the Brazilian Institute of Geography and Statistics (IBGE) and used a subsample of the master sample, which is the basis for IBGE household surveys. The PNS sampling plan considered random cluster sampling in three stages. Detailed information on the PNS sampling process is available elsewhere ${ }^{13}$.

At the end of the fieldwork, 81,167 households were visited, of which 69,994 were occupied, and 60,202 individual interviews were conducted with the selected resident at home $^{14}$. Of these, 34,282 were women, of which 17,987 were 40 years old or older. This study included only women aged 40 years and older who reported having received a medical request for a mammographic examination and performed it. Those who failed to answer some of the questions used in this study and those who had recorded data incorrectly were excluded.

Of the 11,465 who reported receiving a doctor's request to get a mammogram, 10,792 reported having the examination. A total of 221 interviews were excluded because the questionnaire was not filled out correctly or due to lack of information for some variables. Thus, the study sample consisted of 10,571 women.

The question used to obtain the outcome of interest was: "When was the last time you had a mammogram?" The answers were categorized as "less than two years ago"; "two years or more years". The women themselves answered the question, thus reducing the possibility of information bias. The variables were grouped in blocks according to a hierarchical theoretical model.

The first level (distal) included the variables related to sociodemographic conditions: age in years (40 to $49 ; 50$ to $59 ; 60$ to $69 ; 70$ or older); skin color (white or non-white); education (illiterate, complete/incomplete elementary school, complete/incomplete high school, complete/incomplete higher education); conjugal status (with partner, without partner); region (Northeast, North, Central-West, South, Southeast); and household area (urban, rural). 
The second level (intermediate) comprises the variables related to health conditions and lifestyle: perception of health status (good or very good, fair, poor or very poor); self-reported chronic disease (no or yes if one of the following diseases: depression, high blood pressure, cancer, asthma/asthma bronchitis, arthritis or rheumatism, chronic renal failure or chronic obstructive pulmonary disease); alcohol abuse (no or yes if 4 or more doses of alcohol were consumed on a single occasion within the last 30 days); smoking (smokes, smoked or never smoked), also considered tobacco products included cigar, cigarillo, pipe, clove (or Balinese) cigarettes and hookahs (or water pipes); and exercise (yes or no), considered "yes" for those engaged in at least one type of regular exercise or sport in the last three months before the interview date.

The third level (proximal) contains the variables that indicate the use of health services: Pap smear (less than three years ago, three or more years ago, or never); clinical breast examination (CBE) (less than one year ago, one or more years ago, or never); health insurance (yes or no); registration in a family health unit (yes, no or does not know); doctor's visit in the last year (yes or no); discrimination by any health professional (no or yes) - "yes" considered if reported feeling discriminated or treated worse than other people in the health service, because of one of following reasons: lack of money, social class, race/color, type of work, disease type, sexual preference, religion/ belief, gender, age, and other.

In the descriptive analysis, the prevalence of the variables of interest and their respective $95 \%$ confidence interval $(95 \% \mathrm{CI})$ were determined, taking into consideration the effect of the sampling plan for the calculation of point estimates, to ensure the correct interpretation of the results ${ }^{13}$.

Estimates of crude and adjusted prevalence ratios (PR) were applied considering the national level and then by each macro-region. The Poisson regression model with robust variance was used, since the prevalence of the outcome was higher than $10 \%{ }^{15}$. The crude PR for each variable under study was estimated, and the variables with $\mathrm{p} \leq 0.20$ were selected to be included in the multiple model.

In the adjusted analysis, the variables were inserted in the model according to their level or higher level, according to the hierarchical theoretical model. Variables with $\mathrm{p}<0.10$ at a given level remained in subsequent models. After the adjusted analysis of the proximal level, the variables with $\mathrm{p}<0.05$ remained in the final model.

The survey module of the Statistical Software Data Analysis and Statistical Software (STATA) version 12.0 was used to obtain the estimates, since the weight attributed to each interviewee, according to the complex sample design, must be incorporated into the statistical analysis. The weights of each interviewee considered in this study are available along with the microdata on the IBGE website ${ }^{16}$.

PNS was approved by the National Research Ethics Commission (CONEP) of the National Health Council (CNS), Ministry of Health (MS), under Approval No. 328,159, of June 26, 2013. 


\section{RESULTS}

In this study, 10,571 women were evaluated, representing a response rate of $94.0 \%$ among all those aged 40 and older and who had received a request from their doctor to have a mammogram.

The prevalence of getting a mammogram within a period of less than 2 years from the date of the interview was $79.4 \%$, with $49.0 \%$ of the examinations performed through SUS. The percentage of the examination was $74.6 \%(95 \%$ CI $70.1-79.1)$ in the North, $75.7 \%$ $(95 \%$ CI $73.2-78.3)$ in the Northeast, $76.0 \%(95 \%$ CI $73.0-78.8)$ in the Central-West, $80.6 \%$ $(95 \%$ CI $78.0-83.2)$ in the South and $81.2 \%(95 \%$ CI $79.0-83.3)$ in the Southeast.

In Brazil, a higher prevalence of this examination in the last 2 years from the interview date was observed among women aged 40 to 49 years $(86.7 \%)$, self-declared as white $(80.0 \%)$, who lived with a partner $(82.8 \%)$, had higher education $(88.7 \%)$, lived in the Southeast region $(81.0 \%)$, and in an urban area $(76.3 \%)$.

Considering the national level, the analysis adjusted for each hierarchical level is shown in Table 1. In the adjusted analysis of the final model (Table 2), it can be observed that women without any health insurance showed a 14\% higher prevalence of not having the examination. Women over 60, those who rated their health status negatively (fair or poor/ very poor), did not exercise regularly, or felt discriminated by some health professional had an increase of approximately $20 \%$ in the prevalence of not having the examination. A higher percentage of mammography underuse was found in those who reported not seeing a doctor in the last year $(30 \%)$.

A lower prevalence of mammography was found in women who also reported not following recommendations to perform CBE annually $(\mathrm{PR}=11.15 ; 95 \% \mathrm{CI} 8.52-14.59)$ and $\mathrm{Pap}$ smear within 3 years $(\mathrm{PR}=2.78 ; 95 \% \mathrm{CI} 2.51-3.09)$. Women who were not enrolled in a family health unit had a higher prevalence of the examination (PR $=0.85$; 95\% CI $0.77-0.94)$ (Table 2).

Analyzing by macro-region, we can see the variables of each level that remained in the final model. In the first level, it is observed that Northeast women 60 years and older had a $27 \%$ lower mammogram rate, compared with the age group 40 to 49 years. Low education (illiterate, elementary school) was significant in the North, doubling the prevalence of not getting a mammogram compared to those with higher education. And those who lived without a partner in the South had a $36 \%$ lower prevalence of having the screening test than those who lived with a partner (Table 2).

At the secondary level, there was a relationship with lower rate of having a mammogram and the following: women who self-rated their health status as poor/very poor in the Southeast and South $(\mathrm{PR}=1.42 ; 95 \% \mathrm{CI} 1.05-1.93$ and $\mathrm{PR}=1.47 ; 95 \% \mathrm{CI} 1.09-1.97$, respectively), who did not exercise regularly in the South (PR $=1.41 ; 95 \% \mathrm{CI} 1.02-1.95)$ and who had some chronic morbidity in the Central-West (PR = 1.56; 95\%CI 1.23-1.98) (Table 2).

At the proximal level, it was found that the lack of health insurance in the Northeast increased the prevalence of not getting a mammogram by $47 \%$. Not having seen a doctor in the last year was an important factor in the Southeast, Northeast, South and Central-West, ranging from $29 \%$ 
Table 1. Adjusted analysis between mammography and the variables of the three hierarchical levels. National Health Survey, Brazil, 2013.

\begin{tabular}{|l|c|c|c|} 
Variables & $\mathrm{PR}^{\mathrm{d}}$ & $95 \% \mathrm{Cl}^{\mathrm{e}}$ & $\mathrm{p}$ \\
\hline \multicolumn{3}{l}{ Distal level - sociodemographic conditions } \\
\hline
\end{tabular}

Age range (years)

\begin{tabular}{|l|l|l|l}
\hline 40 to 49 & 1.00 & & \\
\hline 50 to 59 & 1.27 & $1.05-1.53$ & 0.011 \\
\hline 60 to 69 & 1.49 & $1.23-1.81$ & $<0.001$ \\
\hline 70 and older & 2.24 & $1.84-2.72$ & $<0.001$ \\
\hline
\end{tabular}

Region

\begin{tabular}{l|l|l|l}
\hline Southeast & 1.00 & & \\
\hline North & 1.38 & $1.14-1.68$ & 0.001 \\
\hline Northeast & 1.22 & $1.05-1.41$ & 0.006 \\
\hline South & 1.02 & $0.86-1.21$ & 0.754 \\
\hline Central-West & 1.29 & $1.10-1.51$ & 0.001 \\
\hline
\end{tabular}

Conjugal status

\begin{tabular}{l|l|l|l}
\hline With partner & 1.00 & & \\
\hline Without partner & 1.26 & $1.11-1.43$ & $<0.001$ \\
\hline
\end{tabular}

\section{Schooling}

\begin{tabular}{|l|l|l|l|}
\hline Higher education, complete/incomplete & 1.00 & & \\
\hline Illiterate & 2.14 & $1.69-2.71$ & $<0.001$ \\
\hline Elementary school, complete/incomplete & 1.94 & $1.54-2.45$ & $<0.001$ \\
\hline High school, complete/incomplete & 1.32 & $1.04-1.67$ & 0.019 \\
\hline
\end{tabular}

Intermediate level - health conditions and lifestyle ${ }^{b}$

Self-rating of health status

\begin{tabular}{|l|l|l|l|}
\hline Good or very good & 1.00 & & \\
\hline Poor or very poor & 1.38 & $1.15-1.66$ & 0.001 \\
\hline Fair & 1.45 & $1.27-1.65$ & $<0.001$
\end{tabular}


Table 1. Continuation.

\begin{tabular}{|c|c|c|c|}
\hline Variables & $\mathrm{PR}^{\mathrm{d}}$ & $95 \% \mathrm{Cle}$ & $p$ \\
\hline \multicolumn{4}{|c|}{ Regular exercise } \\
\hline Yes & 1.00 & & \\
\hline No & 1.72 & $1.45-2.04$ & $<0.001$ \\
\hline
\end{tabular}

Health insurance

\begin{tabular}{|l|l|l|l}
\hline Yes & 1.00 & & \\
\hline No & 1.11 & $0.99-1.25$ & 0.061 \\
\hline
\end{tabular}

Clinical breast examination

\begin{tabular}{|l|c|c|c|}
\hline Within 1 year & 1.00 & & \\
\hline 1 year or longer & 11.08 & $8.45-14.52$ & $<0.001$ \\
\hline Never & 8.35 & $6.18-11.35$ & $<0.001$ \\
\hline
\end{tabular}

Pap smear

\begin{tabular}{|l|l|l|l|}
\hline Within 3 years & 1.00 & & \\
\hline 3 years or longer & 2.78 & $2.49-3.08$ & $<0.001$ \\
\hline Never did & 2.06 & $1.69-2.55$ & $<0.001$ \\
\hline
\end{tabular}

Doctor visit in last year

\begin{tabular}{|c|l|l|l}
\hline Yes & 1.00 & & \\
\hline No & 1.30 & $1.16-1.49$ & $<0.001$ \\
\hline
\end{tabular}

Enrolled in a family health unit

\begin{tabular}{l|l|l|l}
\hline Yes & 1.00 & & \\
\hline No or do not know & 0.86 & $0.78-0.94$ & 0.002 \\
\hline
\end{tabular}

Felt discriminated by health professional

\begin{tabular}{l|c|c|}
\hline No & 1.00 & \\
\hline Yes & 1.20 & $1.03-1.40$ \\
\hline
\end{tabular}

${ }^{a}$ Adjusted prevalence ratio for variables related to sociodemographic conditions (distal level); badjusted prevalence ratio for variables related to sociodemographic conditions and for variables of the level itself (intermediate level); cadjusted prevalence ratio for variables related to sociodemographic conditions, health conditions/lifestyle and for the variables of the level itself (proximal level); PR: prevalence ratio; $95 \% \mathrm{Cl}: 95 \%$ confidence interval. 
Table 2. Final hierarchical model adjusted with respective prevalence ratios and confidence intervals. National Health Survey, Brazil, 2013.

\begin{tabular}{|c|c|c|c|c|c|c|}
\hline Variables & Brazil & North & Northeast & Central-West & Southeast & South \\
\hline \multicolumn{7}{|c|}{ Distal level } \\
\hline \multicolumn{7}{|l|}{ Conjugal status } \\
\hline $\begin{array}{l}\text { Without } \\
\text { partner }\end{array}$ & - & - & - & - & - & $\begin{array}{c}1.36 \\
(1.10-1.68)\end{array}$ \\
\hline \multicolumn{7}{|l|}{ Schooling } \\
\hline Illiterate & - & $\begin{array}{c}2.14 \\
(1.33-3.44)\end{array}$ & - & - & - & - \\
\hline $\begin{array}{l}\text { Elementary } \\
\text { school }\end{array}$ & - & $\begin{array}{c}2.37 \\
(1.41-3.96)\end{array}$ & - & - & - & - \\
\hline High school & - & $\begin{array}{c}1.57 \\
(0.93-2.63)\end{array}$ & - & - & - & - \\
\hline \multicolumn{7}{|c|}{ Age range (years) } \\
\hline 50 to 59 & $\begin{array}{c}1.11 \\
(0.95-1.30)\end{array}$ & - & $\begin{array}{c}1.28 \\
(0.98-1.68)\end{array}$ & - & - & - \\
\hline 60 to 69 & $\begin{array}{c}1.19 \\
(1.01-1.39)\end{array}$ & - & $\begin{array}{c}1.27 \\
(1.00-1.61)\end{array}$ & - & - & - \\
\hline 70 and older & $\begin{array}{c}1.40 \\
(1.21-1.64)\end{array}$ & - & $\begin{array}{c}1.76 \\
(1.35-2.29)\end{array}$ & - & - & - \\
\hline
\end{tabular}

\section{Intermediate level}

Self-rating of health status

\begin{tabular}{l|c|c|c|c|c|c|}
$\begin{array}{l}\text { Poor or } \\
\text { very poor }\end{array}$ & $\begin{array}{c}1.18 \\
(1.02-1.37)\end{array}$ & - & - & - & 1.42 & 1.47 \\
\hline Fair & 1.21 & & - & - & $-1.05-1.93)$ & $(1.09-1.97)$ \\
\hline & $(1.08-1.36)$ & - & - & - & 1.38 & 1.32 \\
\hline
\end{tabular}

Exercise

\begin{tabular}{|l|c|c|c|c|c|c|}
\hline No & 1.22 & & & & & 1.41 \\
\hline
\end{tabular}

Chronic disease

\begin{tabular}{l|l|l|l|c|c|c}
\hline Yes & - & - & - & 1.56 & - & - \\
\hline
\end{tabular}

Proximal level

Health insurance

\begin{tabular}{l|c|c|c} 
No & 1.14 & & 1.47 \\
$(1.02-1.28)$ & - & $(1.19-1.80)$
\end{tabular}


Table 2. Continuation.

\begin{tabular}{|c|c|c|c|c|c|c|}
\hline Variables & Brazil & North & Northeast & Central-West & Southeast & South \\
\hline \multicolumn{7}{|c|}{ Clinical breast examination } \\
\hline $\begin{array}{l}1 \text { year } \\
\text { or longer }\end{array}$ & $\begin{array}{c}11.15 \\
(8.52-14.59)\end{array}$ & $\begin{array}{c}10.65 \\
(5.11-22.2)\end{array}$ & $\begin{array}{c}11.94 \\
(7.47-19.09)\end{array}$ & $\begin{array}{c}9.12 \\
(5.53-15.04)\end{array}$ & $\begin{array}{c}10.91 \\
(6.99-17.03)\end{array}$ & $\begin{array}{c}13.41 \\
(7.37-24.39)\end{array}$ \\
\hline Never & $\begin{array}{c}8.47 \\
(6.25-11.50)\end{array}$ & $\begin{array}{c}8.42 \\
(3.95-17.93)\end{array}$ & $\begin{array}{c}9.58 \\
(5.72-16.05)\end{array}$ & $\begin{array}{c}5.90 \\
(3.18-10.95)\end{array}$ & $\begin{array}{c}7.39 \\
(4.27-12.80)\end{array}$ & $\begin{array}{c}13.17 \\
(6.56-26.45)\end{array}$ \\
\hline \multicolumn{7}{|l|}{ Pap smear } \\
\hline $\begin{array}{l}3 \text { years } \\
\text { or longer }\end{array}$ & $\begin{array}{c}2.78 \\
(2.51-3.09)\end{array}$ & $\begin{array}{c}1.87 \\
(1.34-2.60)\end{array}$ & $\begin{array}{c}2.43 \\
(2.08-2.83)\end{array}$ & $\begin{array}{c}2.54 \\
(2.08-3.11)\end{array}$ & $\begin{array}{c}3.68 \\
(3.06-4.42)\end{array}$ & $\begin{array}{c}2.37 \\
(1.91-2.93)\end{array}$ \\
\hline Never did & $\begin{array}{c}2.08 \\
(1.69-2.55)\end{array}$ & $\begin{array}{c}1.73 \\
(0.97-3.07)\end{array}$ & $\begin{array}{c}1.61 \\
(1.12-2.32)\end{array}$ & $\begin{array}{c}2.25 \\
(1.47-3.45)\end{array}$ & $\begin{array}{c}2.73 \\
(1.86-4.00)\end{array}$ & $\begin{array}{c}1.84 \\
(1.27-2.65)\end{array}$ \\
\hline \multicolumn{7}{|l|}{ Doctor visit } \\
\hline No & $\begin{array}{c}1.31 \\
(1.15-1.49)\end{array}$ & - & $\begin{array}{c}1.32 \\
(1.06-1.63)\end{array}$ & $\begin{array}{c}1.49 \\
(1.12-1.98)\end{array}$ & $\begin{array}{c}1.29 \\
(1.04-1.59)\end{array}$ & $\begin{array}{c}1.40 \\
(1.01-1.93)\end{array}$ \\
\hline \multicolumn{7}{|c|}{ Enrolled in a family health unit } \\
\hline $\begin{array}{l}\text { No or do } \\
\text { not know }\end{array}$ & $\begin{array}{c}0.85 \\
(0.77-0.94)\end{array}$ & - & $\begin{array}{c}0.82 \\
(0.71-0.95)\end{array}$ & $\begin{array}{c}0.73 \\
(0.60-0.89)\end{array}$ & $\begin{array}{c}0.83 \\
(0.71-0.98)\end{array}$ & - \\
\hline \multicolumn{7}{|c|}{ Discrimination } \\
\hline Yes & $\begin{array}{c}1.20 \\
(1.05-1.42)\end{array}$ & - & - & - & - & - \\
\hline
\end{tabular}

in the Southeast to $49 \%$ in the Central-West. In all regions, the CBE and Pap smear variables were the most prominent, and women who did not undergo either of these examinations regularly had a higher prevalence of not having a mammogram. For CBE, estimates ranged from the Central-West at PR $=9.12(95 \%$ CI $5.53-15.04)$ to the South at PR $=13.41(95 \%$ CI $7.37-24.39)$. As for the Pap smear, estimates ranged from the North at PR $=1.87(95 \% \mathrm{CI} 1.34-2.60)$ to the Southeast at PR $=3.68$ (95\%CI $3.06-4.42)$. In the Southeast, Northeast, and Central-West, the interviewees who had their residence enrolled in a family health unit had a higher prevalence of not getting a mammogram (17, 18 and $27 \%$, respectively) (Table 2 ).

\section{DISCUSSION}

The results of this study revealed that approximately $79 \%$ of women aged $\geq 40$ years underwent mammography in the last 2 years from the interview date. Considering only women belonging to the target public of the MS (50 to 69 years old), the percentage of having the screening test was $58 \%$. 
In Brazil, the characteristics related to not having a mammogram at least every 2 years were the following: being 60 or older, having a negative rating of one's health status, not exercising regularly, not having health insurance, not seeing a doctor in the last year, suffering discrimination by some health professional and being enrolled in a family health unit. CBE and Pap smear when not performed in the period recommended by the MS were the factors most associated with not getting a mammogram, which was the same result found in the models for each macro-region.

Analyzing by macro-region, among the sociodemographic variables, there was a tendency for women with less education in the North, 60 and older in the Northeast, and those living without a partner in the South to not have a mammogram at least every 2 years. Variables of the intermediate level were important for the Central-West, where fewer women with some chronic disease underwent mammography, as well as those in the South and Southeast who assessed their health status negatively and those who did not exercise regularly in the South. At the proximal level, it was observed that Northeastern women without health insurance had a higher prevalence of no mammography, like those who did not see a doctor in the Southeast, Northeast, South and Central-West in the last year. Residents in the Southeast, Northeast and Central-West enrolled in a family health unit had a higher prevalence of not having the screening test.

Regarding the Brazilian literature, this is the first study to examine the relationship between sociodemographic aspects, health condition, lifestyle and use of health services and mammography in Brazil, and according to macro-region. The study was population-based, and the outcome variable was chosen from the questions of the individual questionnaire directed to the selected resident. Thus, the women themselves answered whether or not mammography was performed, reducing the possibility of information bias. However, the use of mammography reporting may still be subject to the interviewee's memory bias, as she may respond to what she considers most appropriate, leading to an overestimation of the findings, but there is evidence that information provided in interviews may be used ${ }^{17}$. In addition, the type of study design limits the interpretation of the associations found.

In this study, it was observed that women 60 and older had a lower mammogram rate when compared to women aged 40 to 49 years, which corroborates other national and city studies in Brazil ${ }^{7,10-11,18}$. This result may be linked to the recommendation of several Brazilian medical societies that indicate the examination starting at 40 years of age ${ }^{19}$. In addition, it may be linked to the wide opening for the examination in the private sector, while in SUS most of them fall within the age range for screening recommended by $\mathrm{MS}^{11}$.

Mammography was less frequent among women who evaluated their health status negatively, which has also been reported in the literature ${ }^{6-7,9}$. Despite the expansion of mammography among women who consider their health status "poor/very poor", between 2003 and $2008^{8}$, it was observed that they still have difficulty in accessing mammography. This finding may result from the impairment of these women's health, which may negatively affect their perception of needing to participate in breast cancer screening. This understanding demonstrates the need to promote comprehensive care throughout the care network. 
Women who did not exercise regularly showed a higher prevalence of no mammogram. Therefore, it is inferred that those who exercised regularly had a better perception of care for their own health, because the adoption of this practice is considered a protective factor against the development of breast cancer, being one of the recommendations for the primary prevention of the disease $\mathrm{e}^{20}$. This result is difficult to compare with other studies, because the categorization of the variable physical activity is diverse; however, in general, no relationship was found with getting a mammogram ${ }^{21,22}$.

The feature most strongly associated with not getting a mammogram in the last 2 years was not having a CBE in the last year, followed by not having a Pap smear in the last three years. Similar findings are found in the literature ${ }^{6}$. These associations are probably due to cervical and breast cancer prevention actions being coordinated by primary care and usually being done jointly as part of preventive care for women's health. In this line, we highlight the importance of the active search of those women who do not get preventive examinations periodically. Lower mammography rate was also observed in women who did not see a doctor in the last year, in agreement with other studies ${ }^{6,7}$. The lack of regular doctor visits may indicate difficulty in accessing the consultation and/ or lack of self-care with health in general ${ }^{23}$. Therefore, we believe increased access to doctor visits may have a positive impact on early detection of breast cancer.

In this regard, we emphasize the importance of primary care consultations in promoting the primary prevention and early detection of the disease. However, women enrolled in a family health unit had a higher prevalence of non-examination, which may indicate difficulty in accessing the mammography in the public health care setting. Thus, in addition to access to the screening test request and evaluation of the result by a health professional, women should be assured that they will be able to have the examination performed.

In this context, it is noteworthy that $53 \%$ of women who were not enrolled in a family health unit had no health insurance coverage, while among those who were enrolled, only $30 \%$ were covered (data not shown). This is a factor that may have reflected in the higher mammography prevalence seen in women not enrolled in a family health unit, since having health insurance coverage is still a determining factor in access to mammography $y^{6,7,9,11}$, which was also demonstrated in this study.

The literature indicates that adherence to prevention programs is linked to greater satisfaction with health professionals ${ }^{24}$. Similarly, it was found in this study that women who felt discriminated by some health professional for some reason had a higher prevalence of not submitting to the screening test. Thus, the importance of the health team being prepared to act in face of the diversity of individuals is emphasized.

\section{CONCLUSION}

Efforts should be made to extend mammographic screening for women with lower education in the North and those 60 or older in the Northeast. In addition, our results addressed priority actions in health services, where it is necessary to improve women's access to have 
mammography ordered and done. Besides, it is important to train health professionals on the subject, especially in primary care, to provide comprehensive care, including guidance on primary and secondary prevention of breast cancer in the scope of their actions.

From the knowledge of the factors related to not getting a mammogram, there is the challenge of formulating and implementing public policies in an equitable way, considering the groups most vulnerable to not having the examination performed. By doing so, it is expected that the policy of early breast cancer detection in the country will be strengthened, increasing the chances of early detection in the most diverse population groups, and finally having an impact on the reduction of deaths due to this disease.

\section{REFERENCES}

1. Ferlay J, Soerjomataram I, Dikshit R, Eser S, Mathers $\mathrm{C}$, Rebelo $\mathrm{M}$, et al. Cancer incidence and mortality worldwide: sources, methods and major patterns in GLOBOCAN 2012. Int J Cancer 2015; 136(5): E359-86. https: / / doi.org/10.1002/ijc.29210

2. Instituto Nacional de Câncer José Alencar Gomes da Silva. Coordenação de Prevenção e Vigilância. Estimativa 2018: Incidência de câncer no Brasil. Rio de Janeiro: Instituto Nacional de Câncer José Alencar Gomes da Silva; 2017. (INCA, 128).

3. DeSantis CE, Bray F, Ferlay J, Lortet-Tieulent J, Anderson BO, Jemal A. International Variation in Female Breast Cancer Incidence and Mortality Rates. Cancer Epidemiol Biomarkers Prev 2015; 24(10): 1495 506. https: / / doi.org/10.1158/1055-9965.EPI-15-0535

4. Liedke PE, Finkelstein DM, Szymonifka J, Barrios CH, Chavarri-Guerra Y, Bines J, et. al. Outcomes of breast cancer in Brazil related to health care coverage: a retrospective cohortstudy. Cancer Epidemiol Biomarkers Prev 2014; 23(1): 126-33. https:// doi.org/10.1158/1055-9965.EPI-13-0693

5. Silva PF, Amorim MHC, Zandonade E, Viana KCG. Associação entre variáveis sociodemográficas e estadiamento clínico avançado das neoplasias da mama em hospital de referência no estado do Espírito Santo. Rev Bras Cancerol 2013; 59(3): 361-7.

6. Lima-Costa MF, Matos DL. Prevalência e fatores associados à realização da mamografia na faixa etária de 50-69 anos: um estudo baseado na Pesquisa Nacional por Amostra de Domicílios (2003). Cad Saúde Pública 2007; 23(7): 1665-73. http://dx.doi.org/10.1590/ S0102-311X2007000700018

7. Novaes HMD, Braga PE, Schout D. Fatores associados à realização de exames preventivos para câncer nas mulheres brasileiras, PNAD 2003. Ciênc Saúde Coletiva 2006; 11(4): 1023-35. http://dx.doi.org/10.1590/ S1413-81232006000400023
8. Oliveira EXG, Pinheiro RS, Melo ECP, Carvalho MS. Condicionantes socioeconômicos e geográficos do acesso à mamografia no Brasil, 2003-2008. Ciênc Saúde Coletiva 2011; 16(9): 3649-64. http:/ / dx.doi. org/10.1590/S1413-81232011001000002

9. Rodrigues JD, Cruz MS, Paixão AN. Uma análise da prevenção do câncer de mama no Brasil. Ciênc Saúde Coletiva 2015; 20(10): 3163-76. http:/ / dx.doi. org/10.1590/1413-812320152010.20822014

10. Borges ZD, Wehrmeister FC, Gomes AP, Gonçalves H. Clinical breast examination and mammography: inequalities in Southern and Northeast Brazilian regions. Rev Bras Epidemiol 2016; 19(1): 1-13. https: / / doi.org/10.1590/1980-5497201600010001

11. Silva GA, Souza-Júnior PRB, Damacena GN, Szwarcwald CL. Early detection of breast cancer in Brazil: data from the National Health Survey, 2013. Rev Saúde Pública 2017; 51(Supl. 1): 14s. https: / / doi. org/10.1590/S1518-8787.2017051000191

12. Lages RB, Oliveira GD, Simeão Filho VM, Nogueira FM, Teles JB, Vieira SC. Desigualdades associadas a não realização de mamografia na zona urbana de Teresina-Piauí-Brasil, 2010-2011. Rev Bras Epidemiol 2012; 15(4): 737-47. http://dx.doi.org/10.1590/ S1415-790X2012000400006

13. Souza-Júnior PRBD, Freitas MPSD, Antonaci GDA, Szwarcwald CL. Desenho da amostra da Pesquisa Nacional de Saúde 2013. Epidemiol Serv Saúde 2015; 24(2): 207-16. http://dx.doi.org/10.5123/ S1679-49742015000200003

14. Damacena GN, Szwarcwald CL, Malta DC, Souza Júnior PR, Vieira ML, Pereira CA, et al. O processo de desenvolvimento da Pesquisa Nacional de Saúde no Brasil, 2013. Epidemiol Serv Saúde 2015; 24(2): 197-206. http://dx.doi.org/10.5123/ S1679-49742015000200002 
15. Hirakata VN. Estudos Transversais e Longitudinais com Desfechos Binários: qual a melhor medida de efeito a ser utilizada? Rev HCPA 2009; 29(2): 174-6.

16. Instituto Brasileiro de Geografia e Estatística. Pesquisa Nacional de Saúde 2013: Microdados [Internet]. Instituto Brasileiro de Geografia e Estatística [acessado em $1^{\circ}$ set. 2015]. Disponível em: http://www.ibge. gov.br/home/estatistica/populacao/pns/2013_vol3/ default_microdados.shtm

17. RauscherGH,Johnson TP, Cho YI, WalkJA. Accuracy of selfreported cancer-screening histories: a meta-analysis. Cancer Epidemiol Biomarkers Prev 2008; 17(4): 748-57. https:/ / doi.org/10.1158/1055-9965.EPI-07-2629

18. Sclowitz ML, Menezes AMB, Gigante DP, Tessaro S. Condutas na prevenção secundária do câncer de mama e fatores associados. Rev Saúde Pública 2005; 39(3): 340-9.

19. Urban LA, Schaefer MB, Duarte DL, Santos RP, Maranhão NM, Kefalas AL, et al. Recommendations of Colégio Brasileiro de Radiologia e Diagnóstico por Imagem, Sociedade Brasileira de Mastologia, and Federação Brasileira das Associações de Ginecologia e Obstetrícia for imaging screening for breast cancer. Radiol Bras 2012; 45(6): 334-9. http: / / dx.doi. org/10.1590/S0100-39842012000600009

20. Inumaru LE, da Silveira ÉA, Naves MMV. Fatores de risco e de proteção para câncer de mama: uma revisão sistemática. Cad Saúde Pública 2011; 27(7): 1259-70. http:/ / dx.doi.org/10.1590/S0102-311X2011000700002

21. Lee K, Lim HT, Park SM. Factors associated with use of breast cancer screening services by women aged $\geq 40$ years in Korea: The Third Korea National
Health and Nutrition Examination Survey 2005 (KNHANES III). BMC Cancer 2010; 10: 144. https: / / dx.doi.org/10.1186\%2F1471-2407-10-144

22. Ho SS, Choi KC, Wong CL, Chan CW, Chan HY, Tang WP, et al. Uptake of breast screening and associated factors among Hong Kong women aged $\geq 50$ years: a population-based survey. Public Health 2014; 128(11): 1009-16. https: / / doi.org/10.1016/j.puhe.2014.09.001

23. Novaes CO, Mattos IE. Prevalência e fatores associados a não utilização de mamografia em mulheres idosas. Cad Saúde Pública 2009; 25(Supl. 2): S310-20. http: / / dx.doi. org/10.1590/S0102-311X2009001400013

24. Sheppard VB, Wang J, Yi B, Harrison TM, Feng $S$, Huerta EE, et al. Are health-care relationships important for mammography adherence in Latinas? J Gen Intern Med 2008; 23(12): 2024-30. https: / / dx.doi. org/10.1007\%2Fs11606-008-0815-6

\section{Received on: 04/25/2018 \\ Revised on: 08/30/2018 \\ Accepted on: 10/05/2018}

Authors' contributions: Authors Yonna Costa Barbosa and Alcione Miranda dos Santos contributed substantially to the conception and planning of the research and drafting the manuscript. All authors participated in the analysis and interpretation of the data. Ana Gabriela Caldas Oliveira, Francelena de Sousa Silva and Poliana Pereira Costa Rabêlo carried out a critical review of the content. All authors read and approved the final version of the paper. 